\title{
INDEPENDENCE OF CENTRAL BANKS, INFLATION AND FRACTIONALIZATION OF SOCIETY IN POST-SOCIALIST COUNTRIES
}

\begin{abstract}
Post-crisis literature concentrates on the problem of low inflation economic environment for which traditional factors of macroeconomic instability are rather not important. However, is this approach adequate in the case of post-socialist countries for whom the validity of euro-integration divide of institutional path of development takes place? Can the fact of factionalized societies explain the deviations from traditional form of opposite correlation between central banks independence and inflation? Using a sample of 22 post-socialist countries, it is found that there is inverse (traditional) relation between central bank independence and inflation. The degree of such correlation does not decrease much in the case of a lower inflation period. Development of democracy supports the choice toward higher central banks independence. The level of social conflicts affects inflationary instability and in the same time reduces space for consensus about increasing central banks independence. At the same time, the case of higher central bank independence and higher level of inflation compared to average group level (case of Ukraine) corresponds to the strongest fractionalization of society. This helps to conclude that institute of central bank independence is based on informal political rules of behaviour, incentives to maintain which are rooted in the nature of social disharmony.
\end{abstract}

(C) Victor Koziuk, 2019.

Koziuk Victor, Doctor of Economic Sciences, Professor, Ternopil National Economic University, Ukraine. 


\section{Key words:}

Central banks independence, inflation, factionalized societies, institutional quality, post-socialist countries.

JEL: E58, E59, O23, Q33.

\section{Introduction}

Post-socialist countries have undergone a relatively short period of institutional transformation of central banks. Over the past 15 years, most of them were able to transition monetary authorities from a planned model to the implementation of the best practices of the functioning of central banks. This allowed some countries to meet the formal requirements for EU membership, and certain new EU members - for the euro zone. Fulfilling the integration requirements regarding the statuses of central banks was not a simple task, as evidenced by the analysis of the Convergence Report of the European Central Bank. At the same time, the level of inflation has declined substantially in most of the new EU member states, and is currently around zero, similar to the euro zone.

On the other hand, the reduction of inflation continues to be a difficult task for a number of former Soviet republics. Some of these countries have also been able to transform the central banks institutionally for one reason or another. The traditional view of the inverse relationship between the level of independence of monetary authorities and inflation, finding confirmation at the initial stages of market transformation, would have to undergo some modification. It means that in the case of a significant decrease in inflation, the inverse correlation of central banks' independence is less obvious. In other words, the comparative successes in reforming monetary policy institutions should be accompanied by corresponding successes in reducing inflation. However, that is unlikely.

This paradox can be considered from the angle of relative effectiveness of rather polar monetary regimes, which is typical for the CEE countries. The situation before the global financial crisis could be a starting point for explaining why countries with fixed rates faced a challenge of higher inflation (fixed exchange rate is an amplifier of global liquidity expansion). However, a longer period before 

and Fractionalization of Society in Post-Socialist Countries

and after the crisis of 2008-2009 indicates that the nature of the monetary regime is unlikely to be the main factor in explaining the difference in inflationary trajectories in the post-socialist countries. Most likely, the answer to this question must be sought in the context of the institutional framework of macroeconomic policy. Such foundations help to better understand the cause of deviations in the behaviour of institutions, the tolerance of such a deviation or the lack of social pressure towards bringing an informal trajectory of behaviour of macroeconomic actors to requirements of formal statuses.

Fractionalization of society (lack of social cohesion, concealed or explicit conflicts in society, polar interests of social groups, etc.) can be seen as a driver of permanent failures in the fight against inflation. It can be hypothesised that such fractionalization makes it impossible to consistently implement monetary policy, broadens the zone of conflict between it and fiscal policy, and lays a political and institutional foundation for the weakness of the central bank to implement a strategy for maximizing social welfare. Thus, it is important to clarify how strongly the post-socialist countries are in support of the traditional view of the link between central bank independence and inflation. It is also vital to determine how social fractionalization causes the deviation of inflationary outcomes from those that are theoretically foreseen by the standard view of the inverse relationship between inflation and the autonomy of monetary authorities.

\section{Literature Review}

Positive influence of increasing the independence of central banks on deflation processes is noted in many sources (Grilli, Masciandro, Tabellini, 1991; Cukierman, 1992; Eijffinger S., Schaling E. 1993, March, 49-89). The convincing results of the initial stage of the empirical verification of the connection between the qualitative parameter - the degree of autonomy of the central bank - and the quantitative - the level of inflation, variations in inflation - influenced the changes in ideas about the role of the monetary authorities' status in macroeconomic processes. In particular, the independence of the ECB was seen as a fundamental precondition for the stability of the euro zone and the success of monetary policy in the currency union (Scheller, 2006; Completing Europe's Economic and Monetary Union. Report by J.-C. Juncker, 2015). Subsequently, the studies only confirmed the view that the independence of central banks positively affects the reduction of inflation. Despite the fact that the expansion of the sample countries sometimes puzzled the researchers, at the beginning of the 2000 s, a clear understanding of the peculiarities of empirical relationships was formed. Namely, the independence of central banks is in inverse relation to inflation. There is a difference between actual and formal independence, and one way of identifying such a difference is to determine the average time a head of the monetary authority holds his post (so-called TOR-index). For the most part, the deviation of 
ISSN 2519-4070

the actual independence from the formal one happens in poorer countries. The degree of the correlation may depend on the nature of the specification of the corresponding index. Different ways of quantitatively assessing the status of monetary authorities reflect the specifics of the research and its focus on the problem, and therefore there are opportunities to determine the aspect of the status of central banks that best correlates with the inflation. In developed countries, economic independence is of utmost importance, while in emerging markets, political independence is also crucial. Independence and transparency are often interconnected. The link between the level of central bank independence and the overall macroeconomic situation is often ambiguous and is largely dependent on whether Keynesian or non-Keynesian economies prevail in the economy (Cukierman, Webb, Neyapti, 1992, 353-98; Cukierman, 2008. 722-36; Debelle, Fischer, 1994, 195-221).

Therefore, the results of regional studies are absolutely not accidental. In particular, an analysis of the relationship between inflation and the status of monetary authorities in the Latin American countries and countries of the former USSR confirmed the assumption of the standard viewpoint (Jacome, 2001, 1-40; Jacome, Vazquez, 2005. 1-41; Lubeck, 1999. 1-38). Naturally, the analysis of global trends in this area confirmed that over the course of 1990-2000s the level of political, economic and financial independence of central banks in the world significantly increased, which unsurprisingly affected the stabilizing the median inflation in the global economy (Arnone, Laurens, Segalotto, 2006, 1-56; Arnone, Laurence, Segalotto, Sommer, 2007, 1-53).

Somewhat later, there was increased interest in the issue that determines the choice of countries in favour of more independent central banks. As a rule, studies in this regard are based on an institutional approach. The basic hypothesis is that developed democracy and quality institutions open the way to such institutional improvement as increased independence of central banks. Moreover, even if the initial level of independence of the monetary authorities is not high and price stability is an indisputable priority of monetary policy, central banks demonstrate a relatively high level of transparency, which is their conscious choice, regardless of formal status (Bodea, Hicks, 2012, 1-42.; Crowe, Meade, $2008,1-30$ ). Such approaches paved the way for a broader view of the autonomy of central banks, since they allowed it to be linked to the nature of political and economic institutions in the country. That is, the quality of institutions, in particular the level of development of democratic institutions, correlates positively with the level of independence of central banks, and the link with the level of transparency is even higher (Dincer, Eichengreen, 2014, March, 189-253). It is no coincidence that commodity economies, for example, known for the problem of destructive impact of raw rents on the quality of institutions, show lower level of independence of central banks on average (Koziuk, 2016, March. pp. 6-25.).

An institutional view on the status of monetary authorities is evident in the analysis of the links between social trust and the level of central bank independ- 

and Fractionalization of Society in Post-Socialist Countries

ence. The discovery of the U-like nature of the connection proves that the institutional parameters of the country can often generate much more complicated links between the status of central banks, the motives for a particular policy, or a political choice in favour of the formal and actual role of monetary policy bodies in macroeconomic processes (Berggren, Daunfeldt, Hellstrom, 2012, 1-23.). That is, the institutional structure of the country allows for a conflicting role of the status of monetary authorities in macroeconomic processes. A less independent central bank may be more successful in maintaining price stability if it is supported by overall institutional direction in the country and vice versa (Siklos, 2008, 1-42.; Dreher, Sturm, de Haan, 2007, 1-21).

If social trust is a measure of the nature of institutions and thus the driver of a formal choice as to the status of monetary authorities, then it should follow that its antipode - social fractionalization - must also affect the environment in which the central banks operate. The studies on the impact of the fractionalization on the behaviour of macroeconomic actors are based on the analysis of the connection between the so-called factionalized government / parliament and the effectiveness of fiscal policy. In this context, the results are quite convincing. The main conclusion is that fractionalization of society is transmitted to a heterogeneous government / parliament, who face the problem of finding a compromise, on the basis of which to implement a policy that would satisfy the whole society. The more polar are the interests of groups represented in the government / parliament, the less likely Pareto-optimal policy is. Due to policy inconsistency, propensity for redistributive decisions and frequent changes in macroeconomic guidelines, the country faces a higher debt burden and lesser counter-cyclical behaviour aimed at budget surplus (Crivelli, Gupta, Mulas-Granados, CorreaCaro, 2016, 1-31). This problem is traced most clearly in the critical moments when the structural reforms are needed. Since such reforms affect the interests of polarized groups, there is a tendency to shift the burden of reforms to those social groups that are represented by the least weak political actors. This becomes a source of incitement of social conflicts and frequent changes in power coalitions with corresponding macroeconomic consequences.

The question arises whether the fractionalization of society can be applied to the analysis of the level of central banks' independence and their ability to maintain price stability. The case of post-socialist countries in this regard is rather uncommon. First of all, this is due to the fact that they demonstrate a much lower level of social cohesion than developed countries in Europe. In post-Soviet countries, the level of such cohesion is even lower than in the new EU member states (Acket, Borsenberger, Dickes, Sarracino, 2011, 1-33). Different structural factors may be drivers for the lack of social cohesion. Multi-nationality, regional differences, social marginalization, clan groups, asymmetric access to rent, etc., are the reason why societies form concentrated interest groups with potentially polar views on macroeconomic policies. This means that such a potential conflict is either transferred to the choice of the central bank' status, or leads to creation of an environment within which the central bank cannot fulfil its functions. In other 
words, the presence of polar interests can have dual impact on the formal status of the central bank. On the one hand, it is possible to reach a formal agreement that it should be independent, that is, to agree to minimize the risk of regulator capture. On the other hand, such agreement can be avoided for the explicit purpose of such capture under favourable political circumstances in order to implement redistributive decisions. In any case, it is likely that the level of inflation may not always be correctly correlated with the formal status of the central bank, precisely because of the lack of social cohesion and the existence of a permanent conflict between key social groups.

This view of the problem allows us to form a research objective. It lies in the need to identify the nature of the relationship between the level of central bank independence and inflation in the CEE countries, to verify its compliance with the standard approach (inverse relationship), and to identify cases when the difference between the formal status of central banks and inflation is not described by the standard approach. Accordingly, it will be important to identify the link between the parameters of the social fractionalization and the quantitative measure of the level of central bank independence. Post-socialist countries are chosen because they had roughly the same institutional parameters at the start, but their institutional trajectories significantly diverged later. This will allow us to understand how the institutional trajectory correlates with the degree of conflict in a society, the former of which can result in negative inflation results either with an independent central bank, or with a more controllable one.

\section{Market Transformation, Euro Integration and the Problem of Diverging Institutional Trajectories of Central Bank Development}

The problem of central bank independence in post-socialist countries is often viewed from the perspective of general structural changes during and after the macroeconomic stabilization phase. However, finding correlation between the success in macro-stabilization and the speed of institutional changes in the positioning of central banks within the system of macroeconomic regulators is often quite difficult. The reason for this is that most of the inflationary shock of the transformation period is associated with a radical budget imbalance and a lack of capital market. The formal status of monetary authorities has not always been the decisive factor in explaining the extent of hyperinflation. Although T. Lubeck (Lubeck, 1999, 1-38) shows that the level of central bank independence has determined the extent of inflationary stress during the first years of market transformation, it is much more important to understand the role of such independence in subsequent periods. This is due to the fact that the exit from the hyperinflation band is somewhat given after the normalization of macroeconomic proc- 

and Fractionalization of Society in Post-Socialist Countries

esses, which depends on the overall process of market transformation. Thus, in subsequent periods, the role of the status of monetary authorities should be substantially increased, reflecting the emergence of less marginal macroeconomic conditions. It is in the context of further deflation that actual institutional distortions truly emerge. This either somewhat impedes the convergence of the global median values and the local level of the monetary authority independence, or do not preclude the formal strengthening of the institutional capacity of the central banks. A certain measure of this problem is the prevailing uncertainty about the optimal level of inflation in a society that has undergone hyperinflation and thus faces the need to accelerate economic growth. $\mathrm{H}$. Wagner states that such uncertainty makes it problematic to use the traditional «principal-agent» model, which justifies the need to delegate the responsibility for price stability to the central bank and ensure its more autonomous status (Wagner H. 1998, 1-26). In countries with weak institutions, dynamic inconsistency is often generated not by the agent (central bank), but by the principal (government, parliament), which may mean there is no incentive to a higher level of central bank independence.

Naturally, the tendency to increase the level of central bank independence in post-socialist countries should be based either on the maturation of society or on external pressure on reforms. In both cases, the social cohesion is of fundamental importance. In the first case, when the level of social development becomes the driver of change, one would hardly expect such changes in case of acute conflicts between different social groups or key political actors. Each of the conflicting parties would be inclined to opt for an opportunist avoidance of decreasing the central banks' dependence in order to reap the benefits from it in the event of getting power. The problem of compromise is also significant. A compromise between parties in an active political confrontation is unlikely, even when such a compromise concerns an institution that should be outside of social conflict. It follows, that in the case of a more socially homogeneous society, changes in the status of the central bank will happen not only de-jure, but also de-facto. In other words, in this situation, the increase in the independence of monetary authorities also means the consent of society to a policy of price stability. The benefits from it should be evenly distributed, and, accordingly, the traditional (inverse) connection between the level of inflation and the level of the central bank independence should be observed.

In the second case, the situation is not as unambiguous. For example, the majority of post-socialist countries implemented a stabilization programme with the assistance of IMF. However, a lot less countries implemented programmes with the IMF in subsequent stages, when the Fund set a mandatory structural marker - the change of the institutional status of the central bank. The very fact of a large-scale crisis already indicates the existence of significant gaps in macroeconomic policy. It is possible that they are a reflection of more complex social conflicts when a consistent, healthy macro-policy is impossible within the framework of the current political-institutional form of society. In such a situation, exter- 
nal pressure for reform does not always guarantee a correlation of changes in form and in nature.

External pressure in the form of fulfilling European integration obligations qualitatively differs. Firstly, the requirements for assessing the eligibility of the monetary authorities of the applicant for accession to the EU are rather rigorous and more substantial than the relatively stereotypical requirements of the IMF. Secondly, the consent to the implementation of such changes is already based on a certain level of institutional maturity of society. Thirdly, European integration involves a complex process of institutional convergence, wherein the quality of institutions should approach the EU standards. As part of this process, new paths of interaction between the institutes of democracy and the institutes of macroeconomic policy are formed. This collectively provides the basis for the formation of an institutional trajectory of the central banks in the countries that chose European integration as a priority from offset. An alternative to this trajectory suggests the availability of many variants of interaction between public institutions and the institute of central bank independence. It is here that the role of social conflicts and fractionalization of society will be more obvious. The lack of a link between «maturity of society - formal obligations» allows for a wider range of possible links between the level of inflation and the level of central bank independence.

\section{Central Bank Independence in Transformation Economies and Inflation: Confirmation of Traditional Approaches}

The post-socialist countries may be divided based on the speed of the realization of their civilized choice with its subsequent confirmation in the form of accession to the EU. Thus, it can be assumed that their heterogeneity in terms of the above institutional trajectories more likely involves the existence of a traditional link between the level of inflation and the level of the monetary authority independence. For the empirical testing of this hypothesis, the GMT-index (Crowe, Meade, 2008, 1-30) and the average inflation rates for 2000-2009 and 2010-2017 (calculated on the basis of IMF data for relevant years) were selected for the 22 post-socialist countries of Europe. The results are shown in Fig. 1-2.

As evidenced by the dependencies shown in Fig. 1-2, post-socialist countries in Europe fully meet the traditional viewpoint on the problem of the relationship between the level of inflation and the level of central bank independence. In the context of both periods, there is an unequivocal inverse and sufficiently close connection. At the same time, the Fig. 2 demonstrates that during the post-crisis period, the density of correlation has weakened somewhat. 


\section{Figue 1}

\section{Central Banks Independence and inflation 2000-2009 years in CEE countries}

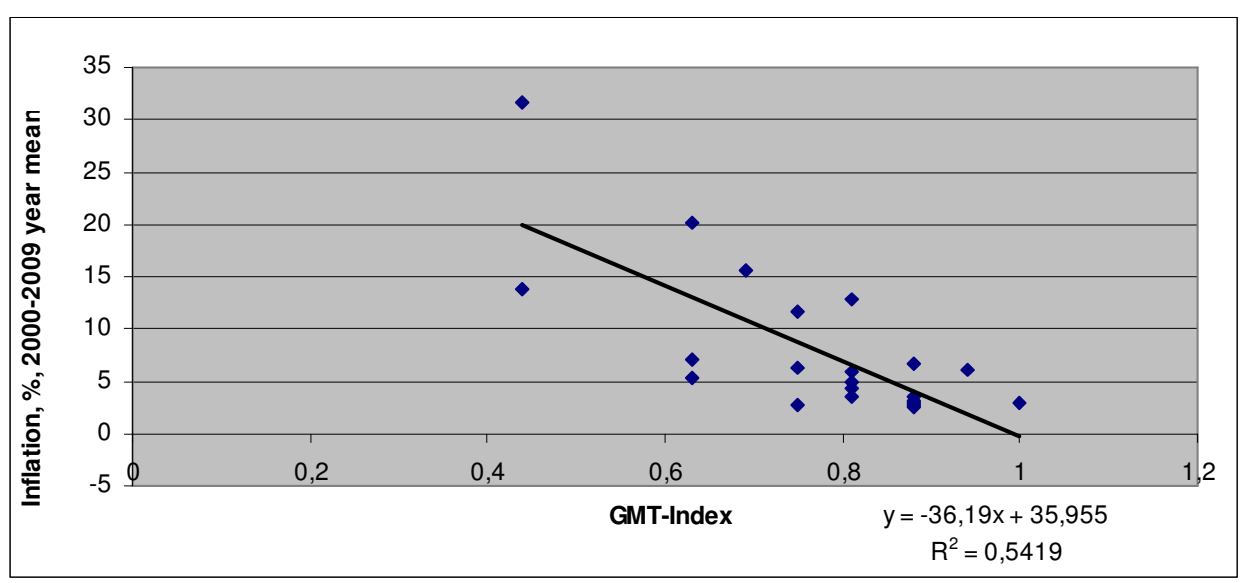

Figue 2

\section{Central Banks Independence and inflation 2010-2017 years in CEE countries}

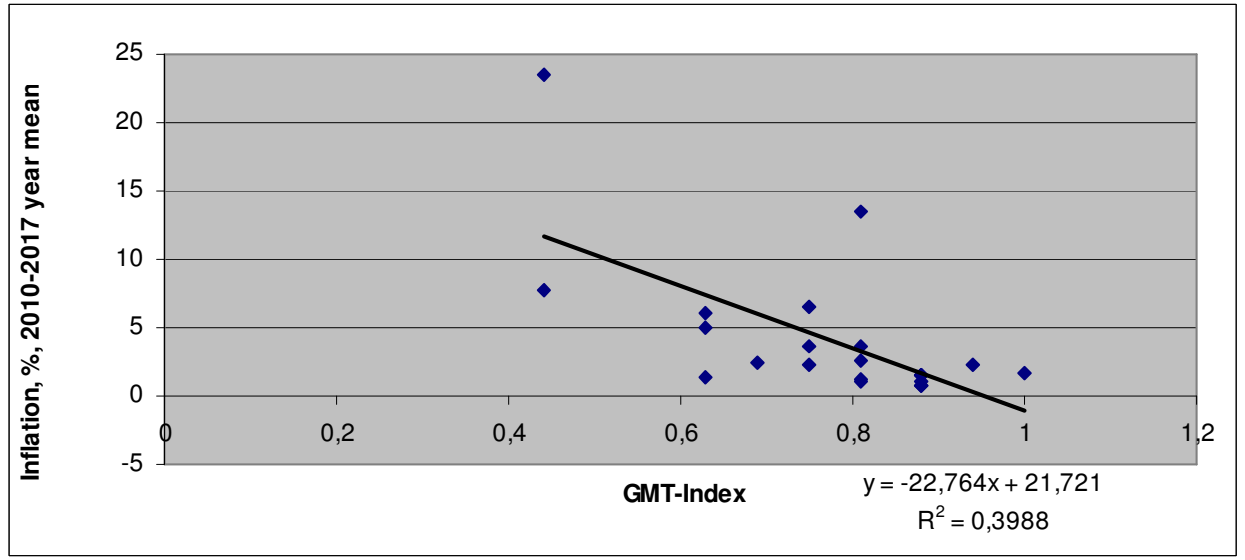

On the one hand, such observation corresponds to earlier trends, which show the peculiarities of the macroeconomic processes taking place in economies with inflation close to zero. We can observe that the line of approximation has shifted downward. That is, for economies that are characterized by extremely 
low inflation, the explanatory capacity of the central bank independence variable is weakened.

On the other hand, the analysed countries as a group continue to show a clear inverse relationship between the analysed indicators. Some weakening of the correlation in such conditions reflects the deepening of differences in the structural determinants of inflationary processes. In other words, post-socialist countries become less homogeneous as a group. In turn, a significant drop in the average inflation and the approximation of the latter towards zero is characteristic only for the new members of the EU. The increasing importance of European GDP-gap in the determination of inflationary pressures in such countries means that the deflationary slope of inflationary processes in the euro area is more likely to be passed on precisely to these countries of the group. However, the weakening of the explanatory capacity of the central bank independence variable for new EU members should not be taken formally. The very fact of the growing importance of the euro zone GDP-gap in the structure of the inflationary processes of the new EU members is also the result of the fact that such countries at one time have chosen an appropriate institutional trajectory for the development of their central banks. That is, the formal and actual increase of their independence made it possible to meet the requirements of the Euro-convergence, so that the process of deepening integration with the EU-EMU affected changes in the structure of inflationary processes. In other words, European integration can indeed be seen as the divide between the institutional trajectories of societies.

\section{Central Bank Independence in Transformation Economies and Inflation: Institutional Approach}

Taking into account the hypothesis about the role of society fractionalization in generating the institutional conditions of inflationary instability, it is necessary to supplement the above analysis of the connection between inflation and the level of central bank independence. For the empirical testing of the hypothesis on the influence of disruptive society factors on the inflation rate in a selected group of countries, the Factionalized Elites Sub-Index of Fragile State Index contained in The Fund for Peace Fragile States Index for the years was used. The supposition that the level of democracy positively affects the level of central bank independence was also tested. The results of the analysis confirmed this (Figures 3-7).

Analysis of the data shown in Fig. 3-7, shows that in general the hypothesis about the role of institutional factors of inflation and drivers of the society's choice of a certain level of central bank independence is confirmed by a sample of post-socialist countries. First, the more democratic countries choose a more independent central 

and Fractionalization of Society in Post-Socialist Countries

bank (Fig. 3). This completely coincides with the results of previous studies on the factors of choice in favour of certain central bank status (Dincer, Eichengreen, 2014, March, 189-253). At the same time, the level of democratic development is in the inverse relationship with the degree of social fractionalization (Fig. 4).

Figue 3

Democracy and Central Banks Independence in CEE countries

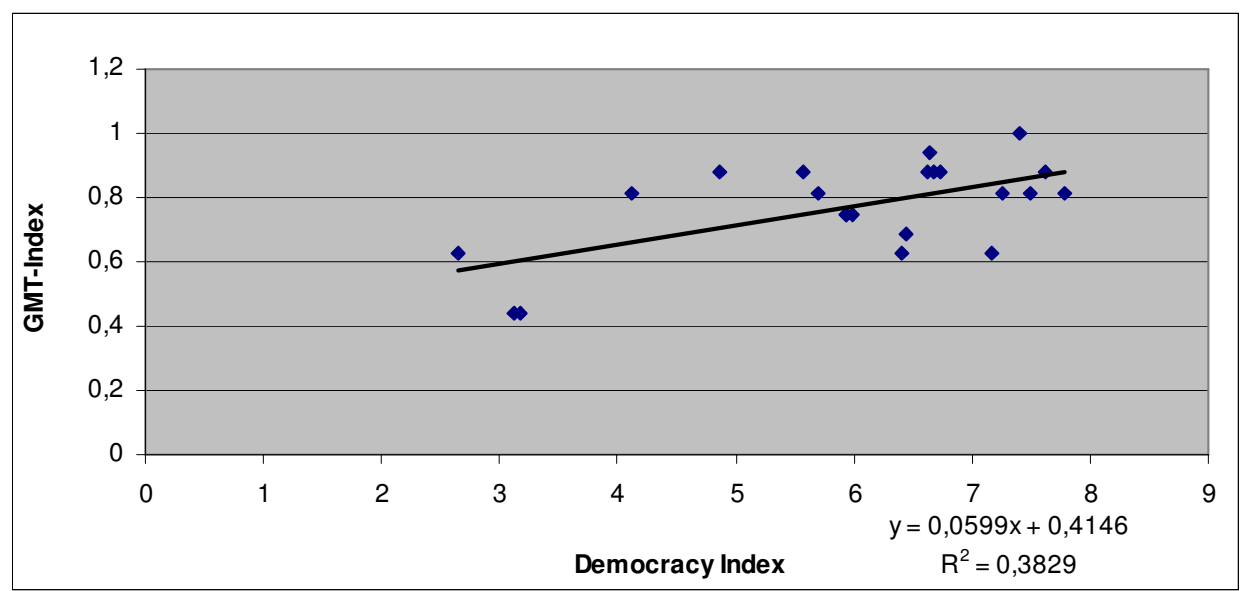

Figue 4

Democracy and Elites Fractionalization in CEE countries

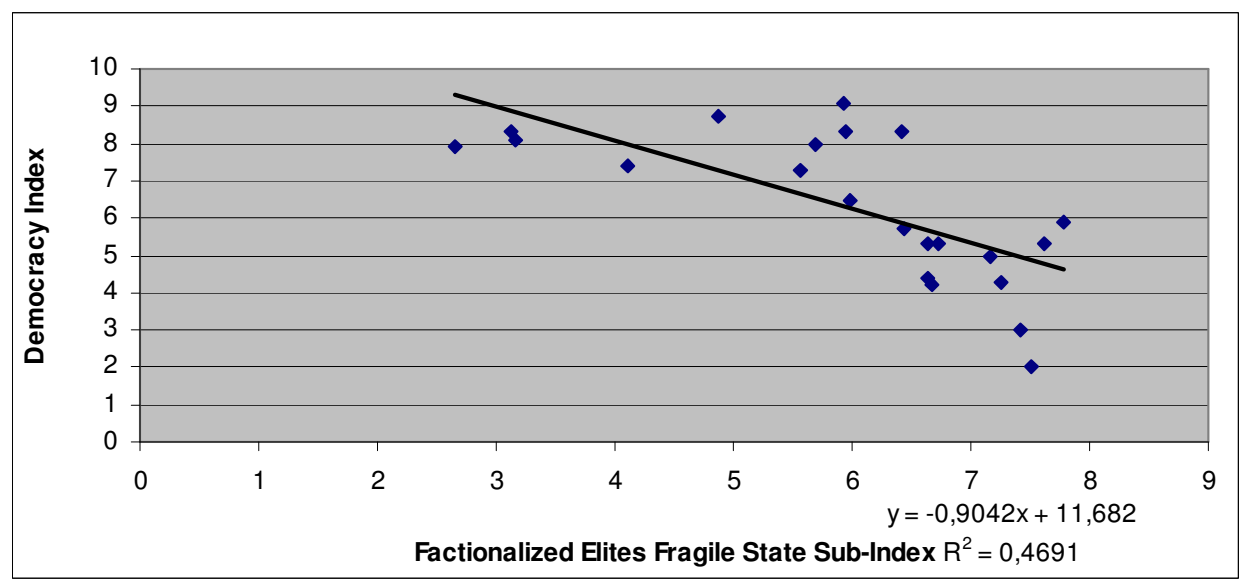


This result indicates that the quality of institutions and the capacity of policy to strengthen them are conditioned by the ability of key social actors to reach a compromise. In the event of a redistributive conflict as a result of social fractionalization, any way to increase economic and political inclusiveness may be paralyzed because of the need to break the redistributive status quo. Lack of democracy development with all the consequences for the quality of governance and capacity building of independent regulators is beholden to the inability of the elites to seek a compromise. Fig. 5. points out that the more factionalized societies are likely to have a less independent central bank. This means that there is an unequivocal link between the lack of social cohesion, the progress of democratic institutions and the positioning of central banks in the institutional «coordinates» of macroeconomic policies.

Figue 5

Elites Fractionalization and Central Banks Independence in CEE countries

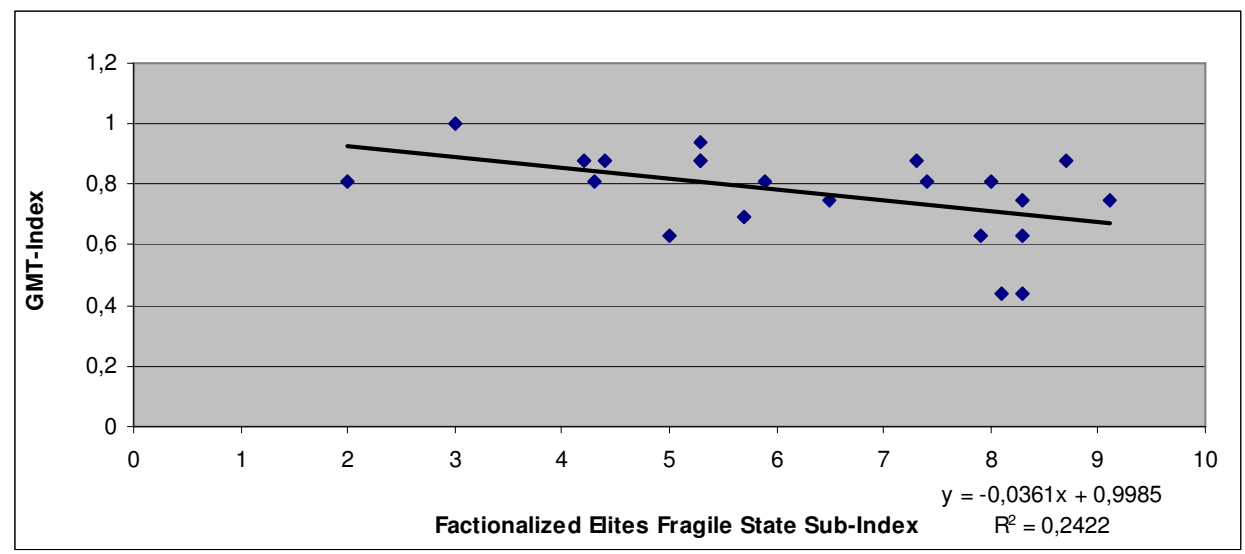

Secondly, taking into account the inverse relationship between the central bank independence and the level of inflation, as well as between the former and the degree of social fractionalization, one can see a direct connection between the latter and inflation. Fig. 6-7, shows that for post-socialist countries, during both periods of time, there was a direct exponential connection. Despite the fact that such a correlation is low, the very fact of its exponential nature shows that in the extreme cases, the lack of social cohesion leads to significant macroeconomic destabilization. This cannot be the result of some abstract macroeconomic factor, but only a result of the inconsistent and contradictory macroeconomic policies, the institutional bases of which are shaky. Fig. 6-7, also show a clearer division into low and high inflation countries, which is deepened by the strengthening of integration ties in the enlarged 

and Fractionalization of Society in Post-Socialist Countries

EU due to a more significant impact of the GDP gap and deflationary deviation on the behaviour of prices in new euro zone members. The deepening of this division is clearly illustrated by the increasing correlation for the period of 2010-2017 (Fig. 7), as compared to the period of 2000-2009 (Fig. 6).

Figue 6

\section{Elites Fractionalization and Inflation 2000-2009 years in CEE countries}

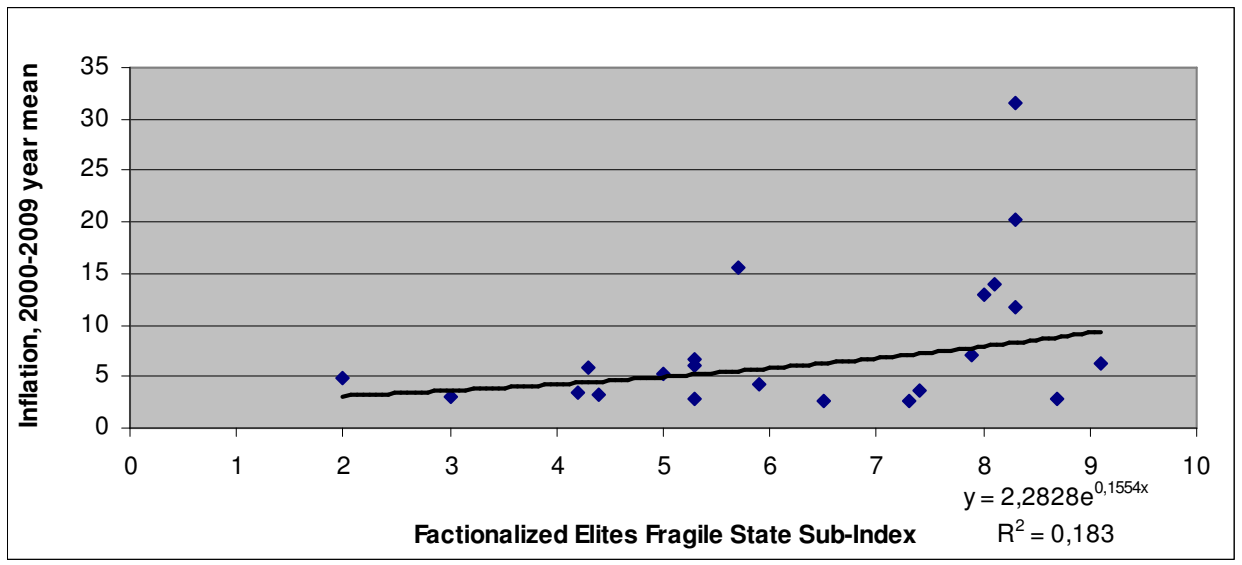

Figue 7

\section{Elites Fractionalization and Inflation 2010-2017 years in CEE countries}

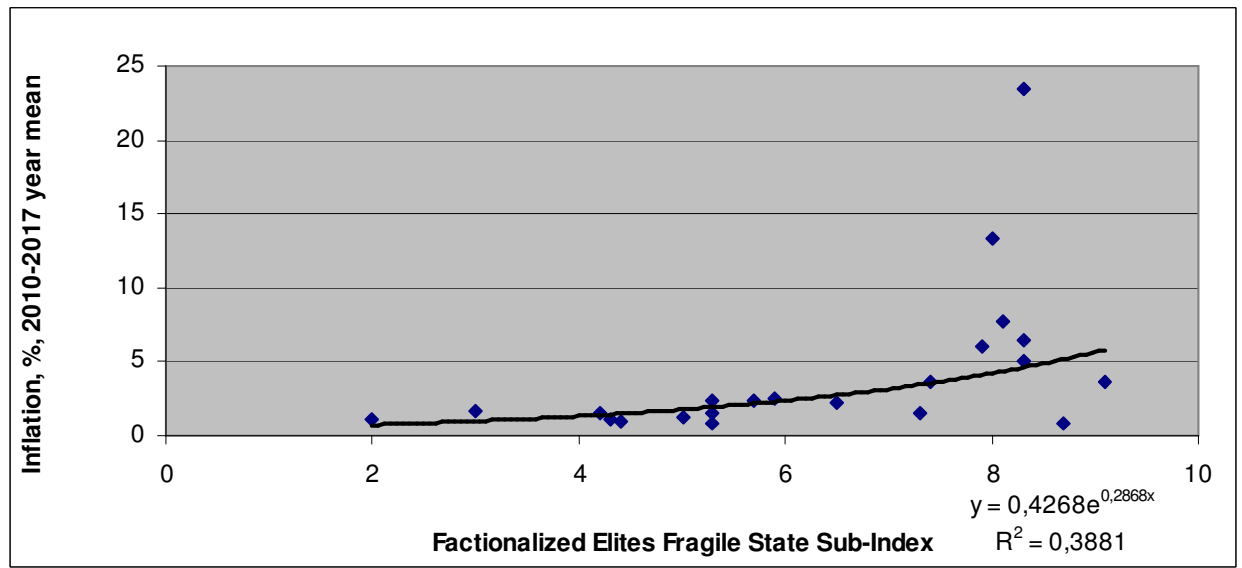


Given the fact that a number of countries are above the trend (Figure 1-2), while demonstrating the comparable level of central bank independence, the question arises as to how the higher / lower values of the GMT-index correlate with higher / lower values of inflation. Such a comparison will help identify the countries in which the nature of the relationship between the level of inflation and the level of central bank independence goes beyond the traditional theory. Data in tables 1-2 demonstrate how countries are positioned and how this positioning has changed over the period of 2000-2009 and 2010-2017. The criterion of a country belonging to this or that subgroup is the presence of indicators - the average inflation rate for the period and the GMT-index - above or below the average for 22 countries as a whole.

Based on the data of tables 1-2, we can come to several fundamental conclusions. First, the overwhelming majority of the new EU member states appeared in a quadrant that united a theoretically predictable case with a higher independence of the central banks and lower inflation. Only exception is Slovakia, which, however, demonstrated that it belonged to quadrant with lower inflation. Bosnia and Herzegovina and Armenia are in the same quadrant as most of the new EU members.

\section{Table 1}

Positioning of countries in the «average inflation over the period the level of central bank independence» system for 2000-2009

\begin{tabular}{|c|c|c|c|}
\hline & \multicolumn{2}{|c|}{ Inflation for the period } \\
\hline & & Below average & Above average \\
\hline \multirow[b]{2}{*}{ GMT-index } & $\begin{array}{c}\text { Below } \\
\text { average }\end{array}$ & $\begin{array}{l}\text { Slovakia, Albania, Geor- } \\
\text { gia, Azerbaijan } \\
\text { Average value of Faction- } \\
\text { alized Elites Sub-Index = } \\
7,13\end{array}$ & $\begin{array}{l}\text { Serbia, Romania, } \\
\text { Moldova, Belarus, Rus- } \\
\text { sia } \\
\text { Average value of Fac- } \\
\text { tionalized Elites Sub- } \\
\text { Index }=7,74\end{array}$ \\
\hline & $\begin{array}{c}\text { Above } \\
\text { average }\end{array}$ & $\begin{array}{l}\text { Estonia, Latvia, Lithuania, } \\
\text { Slovenia, Bulgaria, Po- } \\
\text { land, Czech Republic, } \\
\text { Bosnia and Herzegovina, } \\
\text { Hungary, Croatia, Mace- } \\
\text { donia, Armenia } \\
\text { Average value of Faction- } \\
\text { alized Elites Sub-Index = } \\
5,26\end{array}$ & $\begin{array}{l}\text { Ukraine } \\
\text { Average value of } \\
\text { tionalized } \text { Flites } \\
\text { Index }=8\end{array}$ \\
\hline
\end{tabular}

Note 1. Compiled by the author based on data of [15] and www.imf.org 
Table 2

Positioning of countries in the «average inflation over the period the level of central bank independence» system for 2010-2017

\begin{tabular}{|c|c|c|c|}
\hline & \multicolumn{2}{|c|}{ Inflation for the period } \\
\hline & & \multicolumn{2}{|c|}{\begin{tabular}{l|r} 
Below average & Above average \\
\end{tabular}} \\
\hline & $\begin{array}{l}\text { Below } \\
\text { average }\end{array}$ & $\begin{array}{l}\text { Slovakia, Albania, Georgia } \\
\text { Average value of Faction- } \\
\text { alized Elites Sub-Index = } \\
6,87\end{array}$ & $\begin{array}{l}\text { Serbia, Moldova, Bela- } \\
\text { rus, Russia, Azerbaijan } \\
\text { Average value of Fac- } \\
\text { tionalized Elites Sub- } \\
\text { Index }=8,18\end{array}$ \\
\hline GMT-index & $\begin{array}{c}\text { Above } \\
\text { average }\end{array}$ & $\begin{array}{l}\text { Estonia, Latvia, Lithuania, } \\
\text { Slovenia, Bulgaria, Po- } \\
\text { land, Czech Republic, } \\
\text { Bosnia and Herzegovina, } \\
\text { Hungary, Croatia, Mace- } \\
\text { donia, Armenia, Romania } \\
\text { Average value of Faction- } \\
\text { alized Elites Sub-Index = } \\
5,29\end{array}$ & $\begin{array}{l}\text { Ukraine } \\
\text { Average value of } \\
\text { tionalized } \text { Flites } \\
\text { Index }=8\end{array}$ \\
\hline
\end{tabular}

Note 1. Compiled by the author based on data of (Crowe, Meade, 2008, 1-30.) and www.imf.org

Secondly, membership in the EU is not an exclusive factor for lower inflation. Inflation targets such as Albania and Georgia are capable of sustaining low inflation without pressure from integration commitments. This also applies to such a target of inflation as Armenia. Thirdly, only two countries have changed their positioning. Azerbaijan has aggravated it, and Romania has improved. Fourth, for both periods, only Ukraine is in the quadrant that describes the deviation from the standard theoretical assumption.

The fact that such a small number of countries have changed its positioning points to the existence of strong fundamental factors that determine the logic of central bank behaviour and the dynamics of inflationary processes. In other words, the correspondence of the actual actions of the monetary authorities to the formal status or the inconsistency of it are equally rooted in the motives of society (or key social actors) to tolerate a certain line of behaviour in the implementation of macroeconomic policies. The same applies to the ultimate understanding of the socially optimal level of inflation. Without such an understanding, the possibilities of opportunistic interpretation of the central banks' behaviour increase, enabling dynamic inconsistency, or just incompetent monetary policy.

The average values of the Factionalized Elites Sub-Index, calculated for groups of countries by quadrants, confirm the basic hypothesis of the study. Dur- 
ing both periods, the highest indicator of lacking social cohesion belongs to Ukraine, in which the central bank independence index and inflation are higher than the sample average. The group consisting mainly of the new members of the EU has the lowest level of social fractionalization, as well as above-average level of central bank independence and below-average inflation. The group of countries with the best inflation result and the worst indicator of the monetary authority independence shows a much worse result on the indicator of social fractionalization. However, it is still better than the group of countries in which the value of inflation is higher and the level of central bank independence is higher than the average of the sample. Notably, the change in the positions of Romania and Azerbaijan significantly weakened the importance of the group indicator of the social fractionalization for the period of 2010-2017, as compared to 20002009. It only emphasized the position that in countries that are least homogeneous in terms of social cohesion, high inflationary pressures are generated. Moreover, the status of the central bank here is not always decisive. On the other hand, this indicates that a consensus on the change in the status of the central bank can be achieved in a society much easier than the actual adherence to such a status. And, on the contrary, sometimes focus on actual politics, and not on formal status, may be more important. Most likely, this is a situation with a relatively controlled degree of social fractionalization, or the situation when there are certain compensators of the latter.

From the analysis, it follows that the failures in the monetary policy are rooted in the nature of political conflicts in society, since they are generated by the polar interests of the dominant social actors. The formal increase in the independence of the central bank is not a guarantee of changes in the direction of improving monetary policy and aiming it towards the Pareto-neutral landmark of price stability. However, this does not refute the fact that the status of monetary authorities nevertheless plays a significant role in the process of disinflation. It is a safeguard for negative changes in the event that positive changes have already been initiated at least once. At the same time, it should also be recognized that the institution of central bank independence is based on informal rules of political behaviour, the maintenance of which is substantially influenced by the degree of public fractionalization.

\section{Conclusions}

The basis hypothesis of the article suggests that the traditional view that the relation between the level of central bank independence and inflation must be confirmed for post-socialist countries, taking into account the institutional trajectories of their development. In the case of negative deviation (more independent central bank, higher inflation), fractionalization of society as a source of political instability and, consequently, the cause of inconsistent macroeconomic policies 

and Fractionalization of Society in Post-Socialist Countries

may be an explanation. European integration should be considered a powerful dividing line between the institutional trajectories of central banks in post-socialist countries. The degree of such integration also affects the differences in the mechanisms of the inflation process in the context of countries that are oriented towards the EU and those that aren't. From an empirical point of view, there is a clear inverse relationship between the level of central bank independence and inflation for the 22 post-socialist countries of Europe, as the traditional view of the problem implies. Moreover, the strength of such correlation is not significantly reduced, as implied by the assumptions about the features of low inflationary economies. In parallel, the level of democracy development of is directly related to the level of central bank independence, and inversely related to the degree of social fractionalization. The latter indicator is in direct exponential relation with the level of inflation. Such results confirm that institutional distortions can significantly affect the foundation of macroeconomic policy and the political motivations of those who carry it out. Grouping the countries according to the up / down deviation from the average values of the GMT-index and inflation showed that the lowest level of social fractionalization occurs in countries with an above-average independence of the central banks and below-average inflation. Moreover, the new members of the EU are the basis of this group. A group of countries with a good inflation rate, but a lower level of central bank independence, has a higher level of social fractionalization. The highest levels of social conflict are present in countries that show a deviation up from the average on the sample of inflation. For them, the level of central bank independence is not always significant. However, perhaps the highest index of social fractionalization is evident in the case of Ukraine, which is a deviation from the traditional view of the interdependence between the level of independence of the central bank and inflation. Taken together, this means that social conflicts that are expressed by the polar attitudes of social actors have a significant impact on the effectiveness of macroeconomic policies, and the formal independence of the central bank is not always a guarantee of successful disinflation, although in most cases, the successful maintenance of price stability plays an important role.

\section{References}

1. Grilli, V., Masciandro, D., Tabellini, G. (1991). «Political and Monetary Institutions and Public Financial Policies in the Industrial Countries». Economic Policy 6 (13): 341-92.

2. Cukierman, A. (1992). Central Banking Strategy, Credibility, and Independence: Theory and Evidence. Cambridge, Mass.: MIT Press. 
3. Eijffinger, S., Schaling, E. (1993). "Central Bank Independence in Twe/ve Industrial Countries». Banca Nazionale del Lavoro Quarterly Review 184 (March): 49-89.

4. Scheller, H. (2006). «The European Central Bank: History, Role and Functions». Frankfurt/M. ECB. 2 ed.: 1-232.

5. Juncker, J.-C. (2015). Completing Europe's Economic and Monetary Union. EC. Brussels. 1-24.

6. Cukierman, A., Webb, S., Neyapti, B. (1992). «Measuring the Independence of Central Banks and Its Effect on Policy Outcomes». World Bank Economic Review 6 (3): 353-98.

7. Cukierman, A. (2008). "Central Bank Independence and Monetary Policymaking Institutions: Past, Present, and Future». European Journal of Political Economy. Vol. 24. (4). 722-36.

8. Debelle, G., Fischer, S. (1994). «How Independent Should Central Bank Be?» Goals, Guidelines and Constraints Facing Monetary Policymakers, ed. by J. Fuhrer, Boston: Federal Reserve Bank of Boston.195-221.

9. Jacome, L. (2001). «Legal Central Bank Independence and Inflation in Latin America During the 1990s». IMF Working Paper. WP/01/212.: 1-40.

10. Jacome, L., Vazquez, F. (2005). "Any Link Between Legal Central Bank Independence and Inflation? Evidence from Latin America and the Caribbean». IMF Working Paper. WP/05/75. 1-41.

11. Lubeck, T. (1999). "Central Bank Autonomy, and Inflation and Output Performance in the Baltic States, Russia, and Other Countries of Former Soviet Union, 1995-1997». IMF Working Paper. WP/99/04.: 1-38.

12. Arnone, M., Laurens, B., Segalotto, J-F. (2006). «The Measurement of Central Bank Autonomy: Survey of Models, Indicators, and Empirical Evidence». IMF Working Paper. WP/06/227.: 1-56.

13. Arnone, M., Laurence, B., Segalotto, J-F., Sommer, M. 2007. "Central Bank Autonomy: Lessons from Global Trends». IMF Working Paper. WP/07/88.: 153.

14. Bodea, Cr., Hicks, R. (2012). «Price Stability and Central Bank Independence: Discipline, Credibility and Democratic Institutions». November 6. 1-42.

15. Crowe, C., Meade, E. 2008. "Central Banks Independence and Transparency: Evolution and Effectiveness». IMF Working Paper WP/08/119: 1-30.

16. Dincer, N., Eichengreen, B. (2014). "Central Bank Transparency and Independence: Updates and New Measures». International Journal of Central Banking. Vol. 10. No.1. (March). 189-253. 
17. Koziuk, V. (2016). «Independence of Central Banks in Commodity Economies». Gerald of National Bank of Ukraine. March. pp. 6-25.

18. Berggren, N., Daunfeldt, S.-O., Hellstrom, J. (2012). "Social Trust and Central Bank Independence». Paper Presented at World Congress of Public Choice Societies, Miami.: 1-23.

19. Siklosб P. (2008, 02:). «No Single Definition of Central Bank Independence is Right for All Countries». Paolo Baffi Centre Research Paper. 1-42.

20. Dreher, A., Sturm, J.-E., de Haan J. (2007). «Does High Inflation Cause Central Bankers to Lose Their Job? Evidence Based on a New Data Set». KOF Working Papers. No. 167, 1-21.

21. Crivelli, E., Gupta, S., Mulas-Granados, C., Correa-Caro, C. (2016). «Fragmented Politics and Public Debt». IMF Working Paper. WP/16/190.: 1-31.

22. Acket, S., Borsenberger, M., Dickes, P., Sarracino, F. (2011). «Measuring and Validating Social Cohesion: A Bottom-up Approach». CEPS Working Papers. 2011-08.: 1-33.

23. Wagner, H. (1998). «Central Banking in Transition Countries». IMF Working Paper. WP/98/126.: 1-26. 